SCJR 16, no. 1 (2021): 1-3

\title{
Maria Chiara Rioli A Liminal Church: Refugees, Conversions and the Latin Diocese of Jerusalem, 1946-1956
}

(Leiden and Boston: Brill, 2020), hardcover, xi + 387 pp.

\author{
LAWRENCE E. FRIZZELL \\ lawrence.frizzell@shu.edu \\ Seton Hall University, South Orange, NJ 07079
}

The adjective "liminal" in the title is not an allusion to Victor Turner's wellknown term for a pilgrimage between an old and new status but to the new and complex situation after 1948 of the Latin Patriarchate, the community of the Latinrite of the Catholic Church in the Middle East. The Patriarchate, with its seat in Jerusalem, was re-established in 1847. This diocese included Palestine as well as Transjordan and Cyprus, with 35,000 faithful, and was linked to the Franciscan Custody of the Holy Land, established in 1217 and served by Franciscans from many countries. It faced a difficult decade from 1946-1956 and especially after the major political changes following the creation of the state of Israel in 1948.

This book is the result of a very extensive study in archives, both religious and civil, in Palestine and Israel, as well as sources in the Holy See (Vatican) and many religious orders and congregations. The book depicts the interplay of Roman Catholics of the Latin and six Eastern Rites, with occasional reference to Orthodox Christian and Protestant communities in the Middle East. The wider context is the political and social space shared with Muslims and Jews, both with larger populations.

From the early 1900s the Holy See rejected Jewish efforts to promote a national homeland. By the 1940s Catholic clergy and laity saw Zionism to be a threat coming from a perceived "Jewish-Bolshevik conspiracy" (37). During the war of 1948 Palestinian Catholics described the Israeli soldiers as anti-religious and immoral. The general Catholic fear of Communism cast a shadow over this period and beyond in Palestine, Israel, and Transjordan.

Following the 1947 United Nations General Assembly vote for partition of Palestine (giving Jerusalem a special status) and an increase in regional tension, militant volunteers from Arab nations came to Palestine. Christians joined Muslims in opposition to the partition. What would be the Zionist position regarding Arab 
noncombatants? Early in 1948 Arabs fled from Jewish areas and the Zionists attacked villages near the highways between major Jewish centers. The Arab refugee situation is discussed in detail, though Israel's contemporaneous absorption of a great Jewish migration from Arab and other Muslim lands is not mentioned because it is beyond the scope of this work. In 1948 there were 716,000 Jews in the new state (167); this was doubled by 1951. In general Rioli covers the changing setting in which Catholics in the region lived.

In 1949 the Holy See called for Jerusalem and the Holy Places to be under international supervision. The Holy See declared 1950 to be a Holy Year, immediately linked with the Holy Land, and supported "action for the peace and safeguarding of the holy places" (291). This Jubilee was the context for Pope Pius XII to proclaim the dogma of the Assumption of Mary. This led to the Marian Year in 1954, with a focus on Nazareth and a plan to construct a basilica at the place of the Incarnation. A prominent building project such as this was also meant to challenge the threat of Communism in the Galilee.

Rioli discusses the complex situations the Patriarchate faced. After the creation of Israel, state laws on marriage and education of children included the question of conversion from Judaism to other religions, particularly to Christianity. She writes, "From 1953 marriage and divorce [came] under the control of the rabbinic courts and not of the state... a mixed marriage between a Jew and a non-Jew would be considered null and not legally binding" (206-07). This prevented a Jew from marrying a Catholic. This law affected the Patriarchate's effort to serve lay Catholics in Israel who were in an interfaith relationship.

Linked to this was the question of education of children of a "mixed marriage." Catholic and other Christian schools in Israel were seen as potential settings for conversion of Jewish children (208-12).

The Latin Patriarchate primarily served the parishes of Arab Catholics, but a need arose to serve Catholics married to Jews and the small number of converts whose preferred language was Hebrew. A few priests, converts to Catholicism from other countries, founded in 1955 the Association of St. James (first bishop of Jerusalem) to provide for them. These priests knew the history of efforts in Europe to convert Jews, so they strove to avoid an aggressive approach. Rioli also describes the evolution of this Association in considerable detail and shows how its leaders brought an appreciation for the State of Israel to the attention of Church authorities in Rome and to pilgrims. In contrast to certain Protestant churches, they were not eschatologically focused. For them, "the foundation of Israel did not imply the imminent coming of Christ and the end of time" (250).

After the Israeli press accused the Church of proselytism, the patriarchal vicar, Antonio Vargani, met with journalists on March 10, 1956. He assured them that priests in Israel were coming to serve the resident Catholic population and to guard the Holy Places. He insisted "there is no priest or nun whose sole purpose is to proselytize" (313). Nor was the Church using social action as a means to gain converts. On the contrary, the Hebrew speaking priests helped to prepare many people for the new climate of understanding between Catholics and Jews that was emerging slowly at this time. These were important trends, and "the consequences of 
these developments would become clearer in the 1960s, with the Second Vatican Council and the June 1967 War" (316). This careful study of the Catholic experience in the Middle East in the decade 1946-1956 is part of an international perspective on faith and intercultural relations that now may be explored in a wider context.

Rioli is very thorough in documenting sources. Footnotes are translated into English from six languages, which will be much appreciated by non-specialists. Reference is made to secondary sources on virtually all questions related to the topic. The book is well illustrated, with a 1963 map of the Latin Patriarchate diocese of Jerusalem. However, maps of the U.N. division of the land into Jewish and Palestinian sections and the region after the 1948 war would be appreciated by many readers. There is a helpful 27 page bibliography and a general index. 